\title{
Feeding programs for commercial turkeys at the finishing stage
}

\author{
Christine Maziero Castro ${ }^{1}$ Aline Félix Schneider Bedin ${ }^{2 *}$ iD \\ Marcus Fernando Reginatto ${ }^{3}$ Clóvis Eliseu Gewehr ${ }^{4}$ (D)
}

\author{
${ }^{1}$ Programa de Pós-graduação em Ciência Animal, Universidade do Estado de Santa Catarina (UDESC), Lages, SC, Brasil. \\ ${ }^{2}$ Coordenadoria Especial de Biociências e Saúde Única, Universidade Federal de Santa Catarina (UFSC), 89520-000, Curitibanos, SC, Brasil. \\ E-mail: aline.f.schneider@ufsc.br. "Corresponding author. \\ ${ }^{3}$ BRF S.A., Curitiba, PR, Brasil. \\ ${ }^{4}$ Departamento de Produção Animal e Alimentos, Universidade do Estado de Santa Catarina (UDESC), Lages, SC, Brasil.
}

\begin{abstract}
The aim of this study was to assess the effect of feeding management on performance and carcass yield of male turkeys during finishing stage. 920 male turkeys were used, which were housed in 40 pens; each pen was comprised of experimental unit. The birds, from 91 to 154 days, were submitted to four feeding managements, based on feed intake, that were: ad libitum, where feed was permanently available to birds; controlled with a daily supply of $100 \%$ of recommended feed amount; controlled with $95 \%$ of recommended daily feed amount, and controlled with $90 \%$ of recommended daily feed amount. Each feeding treatment had ten replicates of 23 birds each. Controlled or restricted feeding management reduced feed intake, average weight, and weight gain $(P<0.05)$, and worsened feed conversion $(P<0.05)$. Carcass and leg weight were reduced $(P<0.05)$ from the $5 \%$ restriction related to the recommended. Breast weight was reduced $(P<0.05)$ with a restriction of $10 \%$. No differences were seen when compared to carcass and leg yield and fat deposition ( $P>0.05)$, only breast yield was reduced ( $P<0.05)$ when the birds received $90 \%$ of that recommended by the lineage, compared to the ad libitum feed management. The feeding management of male turkeys with restriction of the recommended feed amount during the finishing stage had a negative effect on the performance of the birds. However, controlled feeding at 100\% of recommended to the lineage reduced feed intake and did not change the carcass weight, breast or leg yield, or fat deposition.
\end{abstract}

Key words: breast yield, carcass yield, feed restriction, Meleagris gallopavo.

Programas alimentares para perus comerciais em fase de terminação

RESUMO: $O$ objetivo deste trabalho foi avaliar o efeito de diferentes manejos alimentares de perus machos na fase de terminação sobre desempenho e rendimento de carcaça. Foram utilizados 920 perus machos, alojados em 40 boxes, onde cada box constituiu uma unidade experimental. As aves, de 91 a 154 dias de idade, foram submetidas a quatro diferentes manejos alimentares, baseados no consumo de ração. Os manejos alimentares foram: a vontade, em que a dieta estava permanentemente disponivel as aves; controlado com o fornecimento diário de $100 \%$ da quantidade recomendada; controlado com o fornecimento diário de $95 \%$ da quantidade de ração recomendada; controlado com o fornecimento diário de $90 \%$ da quantidade de ração recomendada. Cada tratamento alimentar contou com 10 repetições de 23 aves cada. Manejos de alimentação controlados ou restritos reduziram o consumo de ração, peso médio, ganho de peso (P<0.05) e pioraram a conversão alimentar $(P<0.05)$. O peso da carcaça e das pernas foi reduzido $(P<0.05)$ a partir da restrição de $5 \%$ em relação ao recomendado. Já o peso de peito foi reduzido $(P<0.05)$ com a restrição de $10 \%$. Não foram observadas diferenças em relação ao rendimento de carcaça, pernas e deposição de gordura $(P>0.05)$, apenas o rendimento de peito foi reduzido $(P<0.05)$ quando as aves receberam $90 \%$ do recomendado pela linhagem em relação ao manejo a vontade. Manejos alimentares com restrição da quantidade de ração recomendada, na fase de terminação de perus de corte machos, têm efeito negativo sobre o desempenho das aves, no entanto a alimentação controlada em $100 \%$ do recomendado pela linhagem reduz o consumo de ração e não altera o peso ou rendimento da carcaça, peito, pernas e a deposição de gordura.

Palavras-chave: Meleagris gallopavo, rendimento de carcaça, rendimento de peito, restrição alimentar.

\section{INTRODUCTION}

Genetic improvement and nutrition advances have led to an accelerated growth rate in modern lineages of commercial poultry. Besides a balanced formulation, achieving the maximum intake is the most important factor determining growth rate, combined with the efficiency of nutrient use in the diets (FERKET \& GERNAT, 2006). Fast development and weight gain has led to the appearance of locomotor problems. Footpad dermatitis and gait score are positively correlated and affected by a higher body weight (DA COSTA et al., 2014). In addition, in the transect walk method, which provides a practical approach to welfare assessment, locomotor problems, such as, immobility and lameness are important welfare indicators (FERRANTE et al., 2019).

Feed efficiency improvement may be observed by using the feed restriction programs, due to reduced maintenance requirements, which is 
probably related to a decrease in the basal metabolism of feed-restricted birds (ZUBAIR \& LEESON, 1994). Modifying growth patterns by reducing the maintenance requirement is a method to maximize the feed efficiency (URDANETA-RINCÓN \& LEESON, 2002), which may result in metabolic changes such as in the growth hormone (GH) and thyrotropinreleasing hormone (TRH), increase in plasma levels, and the most prominent changes are seen in turkeys that are submitted to feed restriction in the growth phase (PROUDMAN \& OPEL, 1981).

Higher weight at slaughtering has been achieved due to increased feed intake, which is a result of advancing genetics and nutrition (URDANETARINCON \& LESSON, 2002; HAVENSTEIN et al., 2007, JANG et al., 2009). However, the ad libitum feed consumption can lead to metabolic and skeletal disorders and increased fat deposits in the carcasses, resulting in economic losses. These situations increase an interest in feed restriction programs, which may result in abdominal and body fat reduction, but with some reduction in the final weight of the birds (YU \& ROBINSON, 1992).

Feed restriction programs have been used as a strategy to combat these problems. They look forward to producing animals with maximum lean body mass, better feed conversion, and maximum body weight (TUMOVÁ et al., 2002). For commercial turkeys at the finishing stage, reports on late restriction are rare, where it is intended to improve the feed consumption ratio on zootechnical indicators, such as live weight and feed conversion (YU \& ROBINSON, 1992).

In literature, it is possible to find studies that demonstrate the effects of feed restriction on turkey breeders (CROUCH et al., 2002a; CROUCH et al., 2002b) or commercial turkeys in the first stages of rearing (TUMOVÁ et al., 2002). However, in the finishing stage, studies are still scarce. This study hypothesizes that it is possible to restrict the feeding of turkeys by $10 \%$ during the finishing stage, without any loss in the performance and yield of the carcass and cuts, allowing a reduction in production costs. Based on the above, this study aims to assess the effect of different feed restriction treatments on commercial lineage male turkeys, on their performance, and the carcass, breast, leg, and fat weight and yield during the finishing stage.

\section{MATERIALS AND METHODS}

\section{Animals, housing, and experimental design}

The experiment was carried out at the experimental turkey farm from the BRF company, in the western region of Santa Catarina state, southern Brazil, located at coordinates $27^{\circ} 05$ ' 47 ' $\mathrm{S}, 52^{\circ} 37^{\prime}$ 06 " W. The poultry house had 1.2 inches netting and side translucent plastic curtains, and it was divided into 40 box parcels of $8 \mathrm{~m}^{2}$ separated by 1.0 -inch netting. Each parcel had a drinker, a tubular feeder, which was specific for turkeys, and the floor was covered with shaving litter.

A total of 920 Nicholas 700 male turkeys, one-day-old, (Meleagris gallopavo) was housed and reared according to the lineage guide (NICHOLAS, 2013b) and fed ad libitum. When they were 91 days old, the birds were weighed and randomly distributed into the pens that constituted the experimental units. The photoperiod during the experimental period was naturally increased from 10 hours to 12 hours of light per day.

\section{Experimental diets}

The birds were submitted to four feeding managements (treatments), based on the feed intake per bird, as established by the Nicholas Turkeys Lineage Guide (2013a), according to age. The four feeding treatments were: (1) ad libitum (AL), where the feed was permanently available to the birds; (2) controlled with a daily supply of $100 \%$ of the recommended feed amount (Cont100); (3) controlled with $95 \%$ of the recommended daily feed amount (Cont95), and (4) controlled with $90 \%$ of the recommended daily feed amount (Cont90). For controlled feeding managements, the feed amount supplied was divided into two portions a day and distributed at 8 a.m. and 3 p.m.

The diets (Table 1) were formulated according to the nutritional requirements recommended by the lineage guide (NICHOLAS, 2013a). The corn used in the ration production had 750 micrometers of mean geometric diameter (MGD), and the physical form was pelleted into a $4 \mathrm{~mm}$ pellet with $80 \%$ PDI (pellet durability index). The feed amount provided increased progressively each week according to the age (Table 2) and the left over from the ad libitum treatment measured at the end of each week. Water was provided ad libitum.

\section{Data collection}

Animal performance was assessed between the thirteenth and the twenty-second week by feed intake ( $\mathrm{kg} / \mathrm{bird} /$ day), live weight $(\mathrm{kg} / \mathrm{bird})$, weight gain $(\mathrm{kg} / \mathrm{bird})$, and feed conversion $(\mathrm{kg} / \mathrm{kg})$, and the data were obtained weekly. The weight of the birds was measured by collective weighting after 12 hours of fasting. All performance data were corrected by discounting the mortality. 
Table 1 - Feed nutritional and calculated composition for the different feeding management of turkeys in the final phase.

\begin{tabular}{|c|c|c|c|}
\hline & 91 to 111 & 112 to 126 & 126 to 154 \\
\hline Ingredients & \multicolumn{3}{|c|}{ 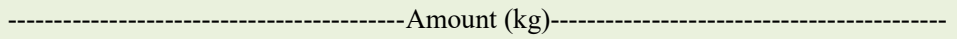 } \\
\hline Maize & 66.4 & 69.2 & 71.7 \\
\hline Soybean meal & 25.1 & 22.6 & 20.1 \\
\hline Monocalcium phosphate & 1.90 & 1.72 & 1.49 \\
\hline Calcitic Limestone & 1.56 & 1.41 & 1.25 \\
\hline Salt & 0.32 & 0.30 & 0.30 \\
\hline Soy oil & 4.05 & 4.34 & 4.63 \\
\hline Liquid lysine & 0.18 & 0.12 & 0.11 \\
\hline Liquid methionine & 0.22 & 0.21 & 0.16 \\
\hline Liquid choline chloride & 0.02 & 0.03 & 0.04 \\
\hline Vitamin and mineral premix ${ }^{1}$ & 0.15 & 0.15 & 0.15 \\
\hline \multirow[t]{2}{*}{ Total } & 100 & 100 & 100 \\
\hline & \multicolumn{3}{|c|}{---------------------------------------Calculated composition----------------------------------- } \\
\hline Metabolizable energy (MJ/kg) & 13.4 & 13.6 & 13.8 \\
\hline Crude protein $(\mathrm{g} / \mathrm{kg})$ & 171 & 160 & 150 \\
\hline Calcium total $(\mathrm{g} / \mathrm{kg})$ & 9.6 & 8.7 & 7.7 \\
\hline Available phosphorus (g/kg) & 4.8 & 4.4 & 3.9 \\
\hline Lysine total $(\mathrm{g} / \mathrm{kg})$ & 10.7 & 9.5 & 8.7 \\
\hline Methionine + cystine total $(\mathrm{g} / \mathrm{kg})$ & 7.5 & 7.1 & 6.5 \\
\hline Threonine total $(\mathrm{g} / \mathrm{kg})$ & 6.6 & 6.2 & 5.8 \\
\hline Choline total (mg/kg) & 1200 & 1200 & 1200 \\
\hline
\end{tabular}

'Vitamin and mineral premix kg of product levels.: retinol: 6000UI, cholecalciferol 4000UI, tocopherol: 50UI, phylloquinone: $2 \mathrm{mg}$, thiamine: $1 \mathrm{mg}$, riboflavin: $5 \mathrm{mg}$, nicotinic acid: $55 \mathrm{mg}$, pantothenic acid: $16 \mathrm{mg}$, pyridoxine: $4 \mathrm{mg}$, biotin: $0.2 \mathrm{mg}$, folic acid: $2 \mathrm{mg}$, cyanocobalamin: $0.02 \mathrm{mg}$, copper: $15 \mathrm{mg}$, iron: $40 \mathrm{mg}$, manganese: $110 \mathrm{mg}$, selenium: $0.3 \mathrm{mg}$, zinc: $80 \mathrm{mg}$, iodine: $2 \mathrm{mg}$.

At the end of the experimental period, at 154 days, two birds from each replicate were randomly selected to assess the weights and carcass, breast, leg, and fat yield. The birds were submitted to eight hours of fasting and were weighed after that (weight 1). After this period, they were sacrificed at a commercial slaughterhouse. The carcasses were hung on hooks with a capacity of 12 units and were sent to the cooling and equalization stations, for seven hours. After this time, it was weighed (weight 2). The carcass yield (\%) was obtained through the relationship between weight 1 and weight 2 . The separation of the carcass into parts was manual and the parts were weighed individually. The yield of the cuts was obtained from the ratio of their weight (cut weight) and the final carcass weight (weight 2). All data were expressed as a percentage (\%).

\section{Statistical analysis}

The experiment was arranged in a completely randomized design, where each feeding management had ten replicates of 23 birds each. Each pen with 23 animals was considered as an experimental unit. The mean growth performance and the weight and yield of the carcass and cuts were submitted to an Analysis of Variance (ANOVA). When differences

Ciência Rural, v.51, n.12, 2021. 
Table 2 - Feed amount g/day provided for Nicholas 700 turkeys according to feed managements with controlled daily supply of $100 \%$ (Cont100), 95\% (Cont95), and 90\% (Cont90) of the lineage guide recommendation between 91 and 154 days old.

\begin{tabular}{|c|c|c|c|}
\hline \multirow[t]{2}{*}{ Age (days) } & \multirow[b]{2}{*}{ Cont 100} & \multirow[b]{2}{*}{ Cont95 } & \multirow[b]{2}{*}{ Cont90 } \\
\hline & & & \\
\hline 91 to 97 & 490 & 466 & 441 \\
\hline 98 to 105 & 524 & 498 & 472 \\
\hline 106 to 111 & 555 & 527 & 500 \\
\hline 112 to 118 & 584 & 555 & 526 \\
\hline 119 to 125 & 610 & 580 & 549 \\
\hline 126 to 132 & 634 & 602 & 571 \\
\hline 133 to 139 & 653 & 620 & 588 \\
\hline 140 to 146 & 669 & 636 & 602 \\
\hline 147 to 154 & 680 & 646 & 612 \\
\hline
\end{tabular}

Source: Adapted from Nicholas Turkeys, 2013.

between the means of feed management (treatment) were observed, the means were separated by the Tukey's test, at a level of $\mathrm{P}<0.05$. Statistical pack MINITAB 16 (2010) was used.

\section{RESULTS}

In the performance assays (Table 3), a higher $(\mathrm{P}<0.001)$ feed intake, live weight, and weight gain were observed in the birds that received
AL feed management as compared to the controlled managements. As the feed restriction increased, there was a reduction $(\mathrm{P}<0.001)$ in feed intake, live weight, and weight gain. Feed management influenced $(\mathrm{P}<0.001)$ the feed conversion, and the AL management provided the best index (3.12) compared to the controlled managements, without a difference $(\mathrm{P}>0.05)$ between Cont 100 and Cont95 managements. The worst conversion (3.42) was observed in turkeys subjected to Cont90

Table 3 - Performance of turkeys fed ad libitum AL. and with daily controlled supplying of 100\% (Cont100), 95\% (Cont95) and 90\% (Cont90) of the amount recommended by Nicholas 700 management guide between 91 and 154 days old.

\begin{tabular}{|c|c|c|c|c|c|c|}
\hline Variables / Treatment & $\mathrm{AL}$ & Cont100 & Cont95 & Cont90 & $\mathrm{SEM}^{2}$ & Prob $^{3}$ \\
\hline Feed intake total $(\mathrm{kg})$ & $35.6 \mathrm{a}$ & $34.7 \mathrm{~b}$ & $33.4 \mathrm{~b}$ & $31.6 \mathrm{c}$ & 0.120 & *** \\
\hline Final weight (kg) & $22.9 \mathrm{a}$ & $22.2 \mathrm{~b}$ & $21.6 \mathrm{c}$ & $20.7 \mathrm{~d}$ & 0.012 & *** \\
\hline Weight gain total $(\mathrm{kg})$ & $11.4 \mathrm{a}$ & $10.8 \mathrm{~b}$ & $10.2 \mathrm{c}$ & $9.26 \mathrm{~d}$ & 0.012 & $* * *$ \\
\hline Feed conversion $(\mathrm{kg} / \mathrm{kg})$ & $3.12 \mathrm{c}$ & $3.20 \mathrm{bc}$ & $3.28 \mathrm{~b}$ & $3.42 \mathrm{a}$ & 0.020 & $* * *$ \\
\hline
\end{tabular}

'Means followed by different letters in the same line differ statistically by the Tukey test $\mathrm{P}<0.05$.

'Mean standard error.

${ }^{3}$ Probability: ${ }^{* * * *} \mathrm{P}<0.0001$ 
management. The feeding management did not affect $(\mathrm{P}>0.05)$ mortality.

Carcass and leg weight (Figure 1) did not differ $(\mathrm{P}>0.05)$ among the birds that received $\mathrm{AL}$ and Cont100 feeding, being higher $(\mathrm{P}<0.05)$ related to the other controlled managements. Breast weight decreased $(\mathrm{P}<0.05)$ as the restriction increased, but did not differ $(\mathrm{P}>0.05)$ between the birds submitted to AL and Cont100 managements, which was similar $(\mathrm{P}>0.05)$ to Cont95, and this to Cont90 ( $\mathrm{P}>0.05)$. The fat weight did not differ $(\mathrm{P}>0.05)$, regardless of the diet management adopted.

The carcass, legs, and fat deposition yield (Figure 2) were not altered $(\mathrm{P}>0.05)$ by the feeding management. However, the breast yield in the Cont90 management presented around a one-percentage-point reduction $(\mathrm{P}<0.001)$ related to the $\mathrm{AL}$ feeding, but it did not differ $(\mathrm{P}>0.05)$ from the other managements.

\section{DISCUSSION}

Controlled feeding management negatively influenced the performance of the birds, and at the end of the experiment, the birds did not reach the indices indicated by the lineage guide. As the feed restriction increased, there was a reduction in consumption and live weight. Turkeys increased their weight fast (NIXEY, 1989), with males multiplying their initial

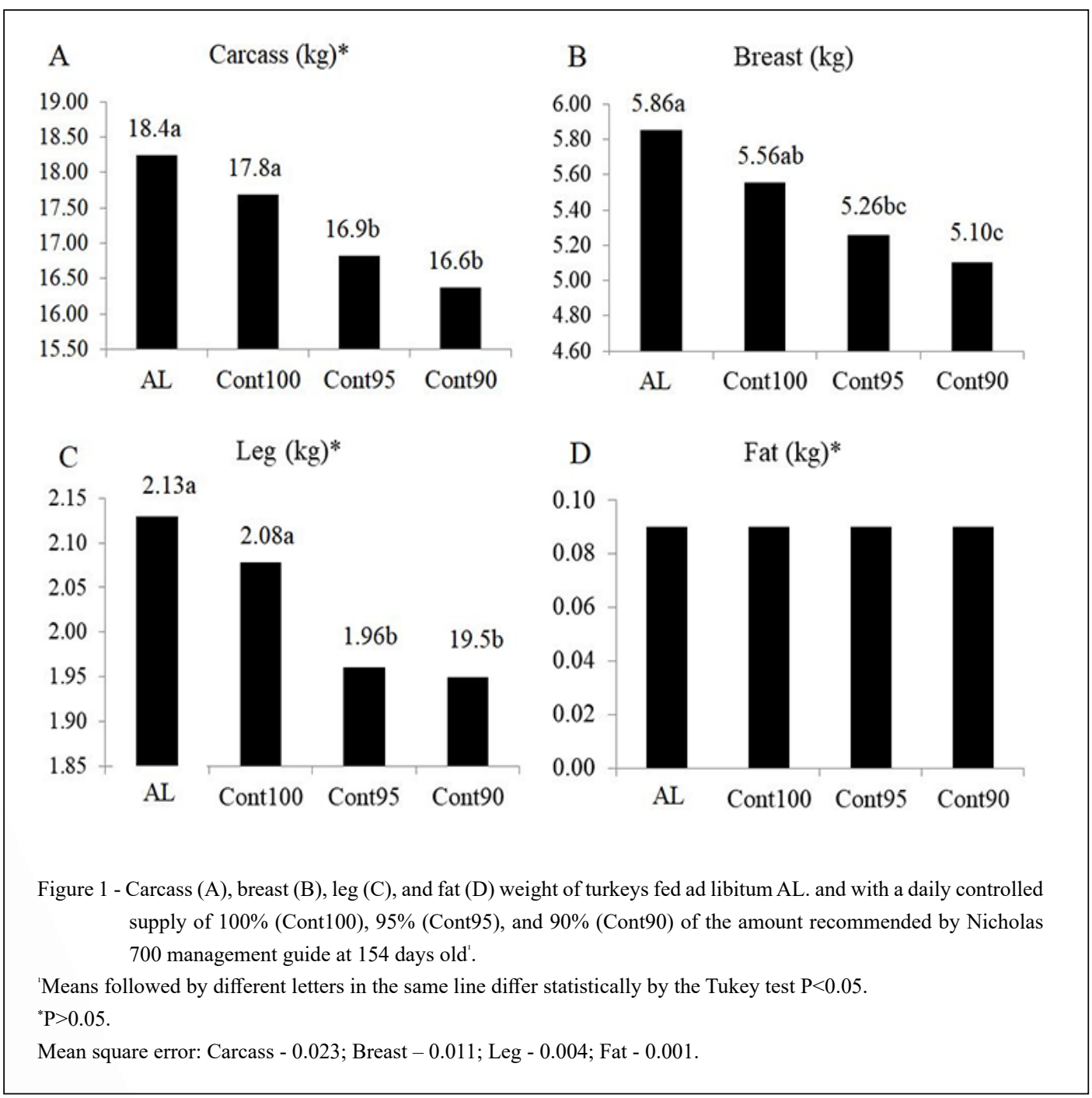

Ciência Rural, v.51, n.12, 2021. 


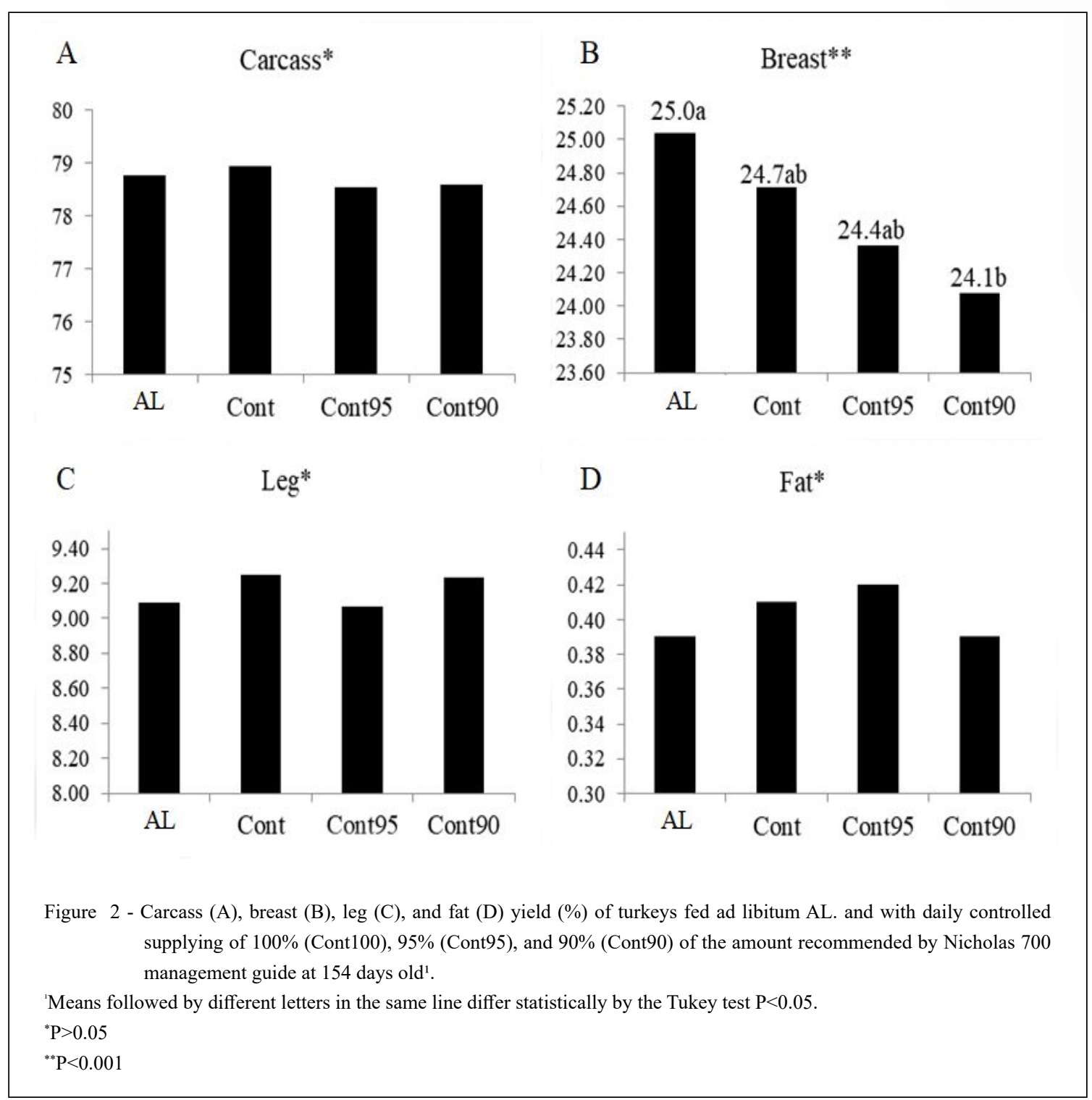

weight by approximately 380 times, when 20 weeks old (NICHOLAS, 2013a). In the current study, it was observed that only the birds fed with AL management achieved the result indicated by the lineage guide, consuming approximately $4 \%$ more feed and gaining $5.3 \%$ higher weight than the birds submitted to the Cont100 management. It should be emphasized that the controlled feed management requires more labor for weighing and distributing feed. Therefore, they must present consistent results that justify it, which was not observed in the present study.

The highest live weight and weight gain of AL-fed birds was attributed to increased feed and metabolizable energy intake (HAVENSTEIN et al.,
2007, ZUBAIR \& LESSON, 1994; YAHAV et al., 2008). On the other hand, controlled managements that consequently decreased the bird ration and ingested amount, implied that there was less nutritional availability for muscular deposition and growth. This result agreed with that obtained by CROUCH et al. (2002a), who verified that the feed restriction limited weight gain in the turkeys. Thus, the hypothesis that the birds fed in a controlled manner and could perform as well as those fed $a d$ libitum, due to the lower energy expenditure to get to the feeder several times a day and reduce wastage, was not confirmed, demonstrating that a controlled and restricted diet reduced the energy available for weight 
gain. These data corroborate with those obtained by PROUDMAN \& OPEL (1981), which indicated that feed restriction affected turkey performance negatively, severely impairing weight gain and feed efficiency. It was highlighted that leg problems had become frequent in turkey production, and was a very complex problem. It was believed that this could be influenced by nutrition, and feed restriction could contribute to minimize this problem. Leg conditions of turkeys had a significant effect on gait velocity and became more serious as turkeys aged and go the heavier (Oviedo-Rondón et al., 2018).

Controlled feeding in turkeys, between 8 and 21 days, resulted in $20 \%-60 \%$ weight gain, lower than the birds fed ad libitum during the restriction period. However, 140-day-old turkeys with restricted feed weighed $400 \mathrm{~g}$ more than birds fed ad libitum throughout the breeding period (TUMOVA et al., 2002). These authors also reported that the compensatory gain started only when the birds were 77 days old. Considering that the restriction ended at 21 days and it took 56 days for the birds to start responding to the restriction, a determining factor in feeding might be necessary, to allow the birds to respond positively. Another negative factor attributed to controlled management is that it could induce competition for food among the birds, hampering the flock uniformity and delaying the development of smaller birds, which implied loss in carcasses and cuts in logistic processing, during slaughtering. Although uniformity was not evaluated in the present study, this was an important variable that could be assessed in future studies.

Controlled feeding of the Cont95 and Cont90 rations worsened feed conversion, even as birds submitted to Cont100 management showed similar conversion to those fed with the AL management. The opposite was found by ZUBAIR \& LEESON (1994), who indicated improvement from feed conversion in controlled feeding programs due to a decrease in the basal metabolism, in birds receiving the restricted feed. Several factors could influence bird response to feed restriction, such as the animal physiological moment and its nutritional requirements, environmental conditions, and it could be possible that males and females respond differently to the restrictions (CROUCH et al., 2002b), which might justify different results.

Breast volume is the most significant factor in the meat processing industry, as it is responsible for $60 \%$ to $70 \%$ of the turkey carcass economic income, and any management to be implemented in an intensive turkey breeding system must take this into account. Molecular studies have demonstrated that dietary restriction delays the neonatal and adult temporal expression pattern of myosin heavy chain isoforms in the major pectoral skeletal muscles of commercial turkeys. Moreover, it is essential to understand the cellular and molecular mechanisms of skeletal muscle development, as they are responsible for turkey meat quality (HUFFMAN et al., 2012). It is only in Cont90 management that the birds have had a lower breast yield compared to AL management, as $10 \%$ of the nutrient supply restriction has resulted in lower muscle deposition. The carcass yield values obtained in this study are like those obtained by MURAWSKA (2013) at 20 weeks. TAHA \& FARRAN (2009) report that feeding strategies may influence carcass quality and composition, which has not been found in the results of this experiment, and it predisposes that only a more severe restriction can cause these effects. CROUCH et al. (2002b) state that body composition changes are more pronounced when restriction occurs in the initial rearing stage and for longer periods, than with restrictions in the final stage, which is consistent with the results found in the present study.

Yield analyses depend on the assessed variable (cut) and the weight of the birds. As it is an association, the expression in percentage eliminates the differences among the bird weights seen in the treatments. Thus, the absolute weight values should also be considered. In this context, no differences have been noticed in the weights of carcasses and cuts of AL-fed birds and those receiving the Cont100 management, which is a promising result concerning feed control. Therefore, it is presumed that the differences found in the live weight of 154-day-old birds must come from other animal tissues, which must be further investigated. According to MORAN et al. (1984), the proportion of breast weight in postcooling carcasses increases with age due to the other parts. Thus, age seems to be the dominant factor affecting breast muscle tissue distribution.

Despite ANOVA did not detect statistical differences in absolute carcass weight, it is important highlight the values are substantial. Birds receiving AL feed management had carcass weight of $18.4 \mathrm{~kg}$, whereas birds receiving Cont100 resulted in $17.8 \mathrm{~kg}$, Cont95 in $16.9 \mathrm{~kg}$ and Cont90 in $16.6 \mathrm{~kg}$ of carcass. Considering turkeys fed AL and those who received Cont90, it was observed numeric difference of 1.8 $\mathrm{kg}$, which represents almost $10 \%$ in carcass weight. Therefore, in basis of absolute values, it can observe a trend in reduction carcass weight as feed restriction increases. It is possible speculate that maybe restriction more than $10 \%$ in the recommended daily feed amount, could lead to a reduction in carcass 
weight with statistical differences, been an important factor that has to be study in future research.

Feeding control, provided $100 \%$ as recommended by the lineage management guide, must be economically assessed and considered, as each bird will consume approximately $1 \mathrm{~kg}$ less feed between the age of 91 and 154 days. At slaughtering, it will show similar carcass, breast, and leg weights, and fat deposition. The cost of the diet is the factor that has the greatest impact on the total cost of commercial turkeys. Therefore, any management that implies a reduction in its value and also does not detract the slaughtering of cuts, must be further studied, as long as animal welfare conditions are considered.

The higher feed intake seen in birds that were fed ad libitum did not change the carcass weight or fat yield. Feed restriction programs were used as a strategy to produce animals with lower fat percentages (TUMOVA et al., 2002). Slaughtering age was an important factor to consider when assessing the carcass yield and cuts. In this context, the slaughtering age used in this study was the one usually used in commercial farms (154 days old). It is necessary to perform studies that show the controlled or restricted feeding implications on metabolic and skeletal problems, which are currently common in turkey production, because, based on these; the quantitative feed restriction presents consistent results in other animal species (SAHRAEI, 2012).

It can be concluded that feed-restricted management in the finishing stage of male commercial turkeys reduces the zootechnical performance and carcass and cuts weight, without altering their yield. Birds fed ad libitum achieved the result indicated by the lineage guide, by consuming approximately $4 \%$ more feed and gaining 5.3\% higher weight than the birds submitted to controlled feeding.

\section{BIOETHICS AND BIOSSECURITY COMMITTEE APPROVAL}

All animals in this study were treated according to the ethical standards of the Animal Experimentation Ethics Committee at the Universidade do Estado de Santa Catarina. The project was approved under the protocol number 1.47.13.

\section{DECLARTION OF CONFLICT OF INTERESTS}

The authors declare no conflict of interest. The founding sponsors had no role in the design of the study; in the collection, analyses, or interpretation of data; in the writing of the manuscript, and in the decision to publish the results.

\section{AUTHORS' CONTRIBUTIONS}

All authors contributed equally for the conception and writing of the manuscript. All authors critically revised the manuscript and approved of the final version.

\section{REFERENCES}

CROUCH, A. N. et al. Effect of physical feed restriction during rearing on large white turkey breeder hens: 1 . Growth performance. Poultry Science, 81: 9-15, 2002a. Available from: < https://doi.org/10.1093/ ps/81.1.9>. Accessed: Jan. 20, 2017. doi: 10.1093/ps/81.1.9.

CROUCH, A. N. et al., Effect of physical feed restriction during rearing on Large White turkey breeder hens: 3. Body and carcass composition. Poultry Science, 81: 1792-1797, 2002b. Available from: $<$ https://doi.org/10.1093/ps/81.12.1792>. Accessed: Jan. 20, 2017. doi: $10.1093 / \mathrm{ps} / 81.12 .1792$.

DACOSTA, M. J. et al. Footpad dermatitis severity on turkey flocks and correlations with locomotion, litter conditions and body weight at market age. Journal Applied of Poultry Research, 23: 268279, 2014. Available from: <https://doi.org/10.3382/japr.201300848> . Accessed: Jun. 17, 2016. doi: 10.3382/japr.2013-00848.

FERKET, P. R.; GERNAT, A. G. Factors that affect feed intake of meat birds: a review. International Journal Poultry Science, 10: 905-911, 2006. Available from: <https://doi.org/10.3923/ ijps.2006.905.911>. Accessed: Nov. 11, 2016. doi: 10.3923/ ijps.2006.905.911.

FERRANTE, V. et al. Differences in prevalence of welfare indicators in male and female turkey flocks (Meleagris gallopavo). Poultry Science, 98: 1568-1574, 2019. Available from: <http:// dx.doi.org/10.3382/ps/pey534>. Accessed: Nov. 13, 2016. doi: $10.3382 / \mathrm{ps} /$ pey534.

HAVENSTEIN, G. B. et al. Comparison of the performance of 1966 - versus 2003 -type turkeys when fed representative 1966 and 2003 turkey diets: growth rate, livability, and feed conversion. Poultry Science, 86: 232-240, 2007. Available from: <https://doi.org/10.1093/ ps/86.2.232>. Accessed: Dez. 15, 2016. doi: 10.1093/ps/86.2.232.

HUFFMAN , K . et al. Feed restriction delays developmental fast skeletal muscle myosin heavy chain isoforms in turkey poults selected for differential growth. Poultry Science, 91: 3178-3183, 2012. Available from: <https://doi.org/10.3382/ps.2012-02367>. Accessed: Jan. 21, 2017. doi: 10.3382/ps.2012-02367.

JANG, I. S.; et al. Effect of qualitative and quantitative feed restriction on growth performance and immune function in broiler chickens. Asian-Aust. Journal Animal Science, 22: 388-395, 2009. Available from: <https://doi.org/10.5713/ajas.2009.80513>. Acessed: Jan, 23, 2017. doi: 10.5713/ajas.2009.80513.

MINITAB 16.Minitab. Minitab, State College, PA, 2010.

MORAN JR, E. T. et al. Response of large tom turkeys differing in growth characteristics to divergent feeding systems: performance, carcass quality, and sensory evaluation. Poultry Science, 63: 1778-1792, 1984. Available from: <https://doi.org/10.3382/ ps.0631778>. Acessed: Dez, 2019. doi: 10.3382/ps.0631778.

MURAWSKA, D. Age-related changes in the percentage content of edible and nonedible components in turkeys. Poultry Science, 92: 
255-264, 2013. Available from: <https://doi.org/10.3382/ps.201202611>. Acessed: Jan, 15, 2017. doi: 10.3382/ps.2012-02611.

NICHOLAS T. Commercial nutrition recommendations. 2013 a. Available from: <http://www.aviagenturkeys.com/us/documentlibrary.aspx>. Acessed: Mar, 21, 2017.

NICHOLAS TURKEYS. Management essencials for commercial Turkeys, 2013b. Available from: <http://www.aviagenturkeys. com/us/document-library.aspx>. Acessed: Mar, 21, 2017.

NIXEY, C.; GREY, T. C. Recent advances in turkey science. London, UK: Butterworks. 1989. 373p. OVIEDO-RONDÓN, E. O. Influence of gait on bone strength in turkeys with leg defects. Poultry Science, 97:2621-2637, 2018. Available from: <https://doi.org/10.3382/ps/ pey142>. Acessed: Jan, 23, 2017. doi: 10.3382/ps/pey142.

PROUDMAN, J. A.; OPEL, H. Effect of feed or water restriction on basal and TRH-stimulated growth hormone secretion in the growing turkey poult. Poultry Science 60: 659-667, 1981. Available from: $<$ https://doi.org/10.3382/ps.0600659>. Acessed: Mar, 25, 2016. doi: 10.3382/ps.0600659.

ROBINSON, F. E. et al. Growth performance, feed efficiency and the Incidence of skeletal and metabolic disease in full-fed and feed restricted broiler and roaster chickens. The Journal of Applied Poultry Research, 1: 33-41, 1992. Available from: <https://doi. org/10.1093/japr/1.1.33>. Acessed: Fev, 21, 2019. doi: 10.1093/ japr/1.1.33.

SAHRAEI, M. Feed restriction in broiler chickens production: a review. Global Veterinaria 8: 449-458, 2012. Available from: $<$ https://doi.org/10.2298/bah1202333s >. Acessed: Fev, 21, 2019. doi: 10.2298/BAH1202333S.

TAHA, N. T.; FARRAN, M. T. Comparative study of thigh muscles and bones conformation and some carcass traits of local vs. imported turkey strain. International Journal of Poultry Science, 8: 368-372, 2009. Available from: < https://doi.org/10.3923/ ijps.2009.368.372> . Acessed: Dez, 17, 2016. doi: 10.3923/ ijps.2009.368.372.

TUMOVÁ, E. et al. Effect of early feed restriction on growth in broiler chickens, turkeys and rabbits. Czech Journal Animal Science, 47: 418-428, 2002. Available from: <https://www. researchgate.net/publication/282724468_Effect_of_early_feed_ restriction_on_growth_in_broiler_chickens_turkeys_and_rabbits Vliv rane restrikce na rust brojlerovych kurat krut a kraliku> Acessed: Fev, 21, 2019.

URDANETA-RINCÓN, M.; LEESON, S. Quantitative and qualitative feed restriction on growth characteristics of male broiler chickens. Poultry Science, 81: 679-688, 2002. Available from: <https://doi.org/10.1093/ps/81.5.679>. Acessed: Dez, 01, 2016. doi: $10.1093 / \mathrm{ps} / 81.5 .679$.

YAHAV, S.; R et al. The effect of ventilation on performance body and surface temperature of young turkeys. Poultry Science, 87: 133-137, 2008. Available from: <https://doi.org/10.3382/ ps.2007-00359>. Acessed: Fev, 10, 2017. doi: 10.3382/ps.200700359 .

YU, M. W.; ROBINSON, F. E. The application of short-therm feed restriction to broiler chicken production: a review. The Journal of Applied Poultry Research, 1: 147-153, 1992. Available from: <https://doi.org/10.1093/japr/1.1.147>. Acessed: Mar, 13, 2017. doi: $10.1093 / \mathrm{japr} / 1.1 .147$.

ZUBAIR, A. K.; LEESON, S. Effect of early feed restriction and realimentation on heat production and changes in sizes of digestive organs of male broilers. Poultry Science, 73: 529-538, 1994. Available from: <https://doi.org/10.3382/ ps.0730529>. Acessed: Mai, 10, 2017. doi: 10.3382/ ps.0730529. 